\title{
EPSPS variability, gene expression, and enzymatic activity in glyphosate-resistant biotypes of Digitaria insularis
}

E. Galeano ${ }^{1 *}$, A.M. Barroso $0^{1 *}$ T.S. Vasconcelos ${ }^{1}$, A. López-Rubio A.J.P. Albrecht ${ }^{1}$, R. Victoria Filho ${ }^{1}$ and H. Carrer ${ }^{1}$

${ }^{1}$ Departamento de Ciências Biológicas, Escola Superior de Agricultura "Luiz de Queiroz”, Universidade de São Paulo, Piracicaba, SP, Brasil

${ }^{2}$ Grupo Investigación Ciencias Forenses y Salud, Tecnológico de Antioquia Institución Universitaria, Medellín, Antioquia, Colombia

*These authors contributed equally to this study. Corresponding authors: E. Galeano / H. Carrer

E-mail: estebangg18@hotmail.com / hecarrer@usp.br

Genet. Mol. Res. 15 (3): gmr. 15038730

Received April 26, 2016

Accepted June 6, 2016

Published August 12, 2016

DOI http://dx.doi.org/10.4238/gmr.15038730

Copyright (C) 2016 The Authors. This is an open-access article distributed under the terms of the Creative Commons Attribution ShareAlike (CC BY-SA) 4.0 License.

ABSTRACT. Weed resistance to herbicides is a natural phenomenon that exerts selection on individuals in a population. In Brazil, glyphosate resistance was recently detected in Digitaria insularis. The objective of this study was to elucidate mechanisms of weed resistance in this plant, including genetic variability, allelism, amino acid substitutions, gene expression, and enzymatic activity levels. Most of these have not previously been studied in this species. $D$. insularis DNA sequences were used to analyze genetic variability. cDNA from resistant and susceptible plants was used to identify 
mutations, alleles, and 5-enolpyruvylshikimate-3-phosphate synthase (EPSPS) expression, using real-time quantitative reverse transcriptionpolymerase chain reaction. In addition, EPSPS activity was measured. We found a decrease in genetic variability between populations related to glyphosate application. Substitutions from proline to threonine and tyrosine to cysteine led to a decrease in EPSPS affinity for the glyphosate. In addition, the EPSPS enzymatic activity was slightly higher in resistant plants, whereas EPSPS gene expression was almost identical in both biotypes, suggesting feedback regulation at different levels. To conclude, our results suggest new molecular mechanisms used by $D$. insularis to increase glyphosate resistance.

Key words: Weed resistance; Amino acid substitution; Genetic variability; Gene expression; Enzymatic activity

\section{INTRODUCTION}

Digitaria insularis (L.) Fedde, known as sourgrass, is a Poaceae species native to the Americas, which grows in rangelands, non-agricultural areas, and non-tillage systems (Mondo et al., 2010). Sourgrass is a highly competitive perennial weed with C4 physiology and its reproduction can be accomplished by seed (cross-pollination) or vegetative structures (Machado et al., 2008). Seeds are propagated by wind, water, vehicles, humans, and animals (Machado et al., 2006), and they have 90\% higher germination rates compared with other grasses (Gemelli et al., 2012). For each kg of accumulated dry matter, five plants per square meter can make 1.3 tons of potassium and one ton of nitrogen unavailable in a hectare (Carvalho et al., 2013).

In order to control weeds in agriculture (including $D$. insularis), herbicides such as glyphosate [N(phosphonomethyl)glycine] are often used (Preston and Wakelin, 2008). Glyphosate is a non-selective herbicide that inhibits the EPSPS (5-enolpyruvylshikimate 3-phosphate synthase) gene (Liu and Cao, 2015). It is a low-cost herbicide with a high-control efficacy of several weeds (Preston and Wakelin, 2008). Glyphosate is frequently used in crops with genetically modified organisms conveying glyphosate resistance (Woodburn, 2000). Consequently, carrying out these control strategies contributes to the selection of glyphosateresistant weeds (Franz et al., 1997). At least 24 weed species have spontaneously developed resistance to glyphosate in the last decades (Wang et al., 2014).

Herbicide resistance has been related to several mechanisms, such as reduction in the absorption and translocation of the herbicide (Yu et al., 2007; Barroso et al., 2015), changes in the herbicide sequestration, and modification in the herbicide metabolism rates (Shaner et al., 2012). Reduction of herbicide concentration by vacuolar sequestration (Ge et al., 2010) and selection by herbicide over- and sub-doses (Manalil et al., 2011) have also been reported. These are non-target-site mechanisms. At the molecular level, resistance mechanisms include DNA mutations (Manalil et al., 2011), increases in the genomic EPSPS copy number (Chandi et al., 2012), and EPSPS gene overexpression (Salas et al., 2012), as target-site mechanisms. Resistant plants can present more than one mechanism (Wang et al., 2014). As a target-site mechanism, EPSPS mutations are the cause of the low affinity for glyphosate in plants. There are several mutations, even double mutations, with the most common being the P106

Genetics and Molecular Research 15 (3): gmr.15038730 
mutation; a proline to serine amino acid change (Baerson et al., 2000). According to Gaines et al. (2013), the presence of double mutations in EPSPS can be related to its overexpression. However, overexpression in Amaranthus weeds did not affect plant fitness (Giacomini et al., 2014). At the protein level, amino acid substitutions in the EPSPS enzyme, instead of altering glyphosate affinity, can influence the affinity for the enzyme substrate (phosphoenolpyruvate, PEP), reducing plant development (de Carvalho et al., 2012).

Glyphosate resistance has been described in D. insularis plants in Brazil (de Carvalho et al., 2011). When comparing the plant shoot mass, the resistant biotype in $D$. insularis grows faster than susceptible types, indicating a selection event (de Carvalho et al., 2011). In this plant, non-target glyphosate resistance has also been observed, with different glyphosate absorption, translocation, and metabolic levels in resistant plants (de Carvalho et al., 2012). Also, the occurrence of resistant weeds in the field, such as $D$. insularis, causes productivity losses and increases production costs (Gemelli et al., 2012).

Consequently, with the use of DNA and cDNA sequences of several resistant and susceptible plants from Brazil, the aim of this study was to integrate several approaches at the molecular level including genetic variability, allele analysis, amino acid substitutions, gene expression, and enzymatic activity, in order to elucidate the mechanism of the $D$. insularis resistance among different biotypes.

\section{MATERIAL AND METHODS}

\section{Plant material, sampled areas, and resistance}

Glyphosate-resistant D. insularis seeds were harvested from a citrus field ("Matao") and a corn field ("Unesp"). Glyphosate-susceptible $D$. insularis seeds were harvested from a lettuce field (never treated with herbicide; "Mogi"). All areas are located in the State of São Paulo, Brazil (Table 1). The seeds were collected from 40 different parent plants (from Matao, Unesp, Mogi) and sown in polystyrene pots containing PlantMax ${ }^{\circledR}$ substrate (Agronova, Jundiaí, SP, Brazil), with two plants per pot. Plantlets were grown in a greenhouse at $26^{\circ} / 18^{\circ} \mathrm{C}$ (day/night) with $85 \%$ relative humidity. In order to define resistant plants, fresh biomass 21 days after herbicide application was used. Plants with four expanded leaves were sprayed with glyphosate (Roundup Original, 360 gL-1, Monsanto, São José dos Campos, SP, Brazil) (Barroso et al., 2015). It was obtained a resistance factor value of 2.36 compared with the GR50 values of resistant and susceptible biotypes.

\section{DNA extraction, total RNA extraction, and cDNA synthesis}

Randomly chosen samples of each location (Table 1) were used for DNA extraction using the Doyle and Doyle (1987) method. In addition, four resistant plants from "Matao" and four susceptible plants from "Mogi" were randomly chosen for RNA extraction using the TRIzol $^{\circledR}$ protocol (Life Technologies, Carlsbad, CA, USA). Three leaves of each plant were combined and used for RNA extractions. The DNA and RNA material were quantified by NanoDrop ND-1000 spectrophotometer (NanoDrop Technologies Inc., Wilmington, DE, USA) and the quality was assessed by agarose gel electrophoresis. Total RNA from each sample was treated with DNAse I (Promega, Fitchburg, WI, USA). cDNA samples were synthesized from $1.0 \mu \mathrm{g}$ treated RNA using the SuperScript ${ }^{\mathrm{TM}}$ III First-Strand Synthesis System for quantitative

Genetics and Molecular Research 15 (3): gmr.15038730 
real-time reverse transcription-polymerase chain reaction (qRT-PCR; Life Technologies). For evaluation of genomic DNA contamination, PCR controls were performed using total RNA without reverse transcription as a template, and negative results (absence of bands) were assessed by electrophoresis on a $1 \%(\mathrm{w} / \mathrm{v})$ agarose gel with ethidium bromide staining.

Table 1. DNA samples of susceptible and resistant plants of Digitaria insularis with sample location characteristics.

\begin{tabular}{|c|c|c|c|c|c|c|}
\hline Sample & City & Latitude & Longitude & $\begin{array}{l}\text { Times per year } \\
\text { of glyphosate } \\
\text { application* }\end{array}$ & $\begin{array}{c}\text { Type of } \\
\text { farming } \\
\text { system }\end{array}$ & Altitude (m) \\
\hline Matao_1 & \multirow[t]{5}{*}{ Matão } & \multirow[t]{5}{*}{$21^{\circ} 36^{\prime} 42.15^{\prime \prime S}$} & \multirow[t]{5}{*}{$48^{\circ} 26^{\prime} 38.93^{\prime \prime O}$} & \multirow[t]{5}{*}{$>6$} & \multirow[t]{5}{*}{ Citrus } & \multirow[t]{5}{*}{578} \\
\hline Matao_2 & & & & & & \\
\hline Matao_3 & & & & & & \\
\hline Matao_4 & & & & & & \\
\hline Matao_5 & & & & & & \\
\hline Unesp_1 & \multirow{4}{*}{ Jaboticabal } & \multirow{4}{*}{$21^{\circ} 15^{\prime} 26.77^{\prime \prime S}$} & \multirow[t]{4}{*}{$48^{\circ} 16^{\prime} 43.05^{\prime \prime O}$} & \multirow[t]{4}{*}{$>2$} & \multirow[t]{4}{*}{ Corn } & \multirow[t]{4}{*}{610} \\
\hline Unesp_2 & & & & & & \\
\hline Unesp_3 & & & & & & \\
\hline Unesp_4 & & & & & & \\
\hline Mogi_1 & \multirow[t]{8}{*}{ Mogi das Cruzes } & \multirow[t]{8}{*}{$23^{\circ} 30^{\prime} 30.14^{\prime \prime S}$} & \multirow[t]{8}{*}{$46^{\circ} 09^{\prime} 49.28^{\prime \prime O}$} & \multirow[t]{8}{*}{0} & \multirow[t]{8}{*}{ Lettuce } & \multirow[t]{8}{*}{742} \\
\hline Mogi_2 & & & & & & \\
\hline Mogi_3 & & & & & & \\
\hline Mogi_4 & & & & & & \\
\hline Mogi_5 & & & & & & \\
\hline Mogi_6 & & & & & & \\
\hline Mogi_7 & & & & & & \\
\hline Mogi_8 & & & & & & \\
\hline
\end{tabular}

*Each dose is approx. $4 \mathrm{~L} / \mathrm{ha}$.

\section{Amplification of EPSPS gene, sequence analysis, and alleles}

Primers for EPSPS were obtained from Perez-Jones et al. (2007) to perform the PCR (Table 2) using 100 ng DNA and cDNA samples (Table 2). Bands with amplicons of specified sizes (Table 2) were sliced, purified with the QIAquick Gel Extraction $\mathrm{Kit}^{\circledR}$ (QIAGEN, Valencia, CA, USA), and sequenced (both strands) using the 3100 Genetic Analyzer (Applied Biosystems, Waltham, MA, USA). Both forward and reverse sequences were edited in BioEdit v.7.2.5 (Hall, 1999), in order to find a consensus for each sample, which was subsequently compared against NCBI records using BLASTx. The translation and the correct open-reading frame were obtained using ExPASy (Gasteiger et al., 2003). The amino acid sequences were submitted to a protein family search using PFAM (Finn et al., 2014) to find protein domains for subsequent analyses. A Clustal W (Larkin et al., 2007) was performed with all the cDNA consensus sequences and proteins, in order to find alleles and amino acid substitutions, respectively.

\section{Dendrogram using EPSPS sequences}

The cDNA of "Matao_1" and all DNA sequences were used together to find the introns and exons by alignment. Genetic distances for EPSPS DNA fragments were estimated, using the Kimura model (Kimura, 1980) assuming different rates for substitutions. A distance matrix among samples was produced, followed by a distance cladogram using maximum likelihood.

Genetics and Molecular Research 15 (3): gmr.15038730 
Topology resampling was implemented using a bootstrap technique, with statistical cluster support in the resulting cladogram using MEGA 6.

Table 2. Primers used to amplify Actin $($ Act $)$ and EPSPS by traditional PCR and qRT-PCR in Digitaria
insularis and their parameters.
\begin{tabular}{|l|l|l|c|c|c|c}
\hline $\begin{array}{l}\text { Gene } \\
\text { symbol }\end{array}$ & Type of PCR & Primer sequences (5'-3') forward/reverse & $\begin{array}{c}\text { Tm } \\
\left({ }^{\circ} \mathrm{C}\right)\end{array}$ & $\begin{array}{c}\text { Amplicon length } \\
\text { in cDNA (bp) }\end{array}$ & $\begin{array}{c}\text { Primer } \\
\text { efficiency }\end{array}$ & $\mathrm{R}^{2}$ \\
\hline EPSPS & Standard & $\begin{array}{l}\text { AGCTGTAGTCGTTGGCTGTG/ } \\
\text { GCCAAGAAATAGCTCGCACT }\end{array}$ & 56 & 564 & - & - \\
\hline$A c t$ & Standard & $\begin{array}{l}\text { GTTAGCAATTGGGATGATATGG/ } \\
\text { ATCCAGACACTGTACTTCCT }\end{array}$ & 58 & 794 & - & - \\
\hline EPSPS & qRT-PCR & $\begin{array}{l}\text { TGATGGAGCGTTTTGGCGTGA/ } \\
\text { GCATTTTAGGGGACTTGTA }\end{array}$ & 60 & 94 & 101.7 & $99.8 \%$ \\
\hline Act & qRT-PCR & $\begin{array}{l}\text { ATATGGCTCACACCATCACC/ } \\
\text { CAGGGAGAAGATGACCCAGAT }\end{array}$ & 60 & 133 & 98.4 & $99.3 \%$ \\
\hline
\end{tabular}

*DNA amplicon length is approx. $1190 \mathrm{bp}$.

\section{qRT-PCR}

The primers for qRT-PCR (Table 2) were designed flanking the mRNA EPSPS and Actin (Act) sequences (Table 3 and Table S1) with OligoPerfect ${ }^{\mathrm{TM}}$ Designer (Life Technologies). The primer specificity was assessed using the melting curve and the amplification efficiency was evaluated with the correlation coefficient and slope values obtained from the standard curve. The qRT-PCR mixture contained $25 \mathrm{ng}$ each sample, $50 \mu \mathrm{M}$ each primer, $12.5 \mu \mathrm{L}$ $\mathrm{SYBR}^{\circledR}$ Green PCR Master Mix (Applied Biosystems), and PCR-grade water up to $25-\mu \mathrm{L}$ total volume. Each gene reaction was performed with two technical replicates. PCR amplifications without template were used as negative controls. The reactions were performed employing the StepOnePlus ${ }^{\mathrm{TM}}$ System (Applied Biosystems) under the following conditions: 2 min at $50^{\circ} \mathrm{C}, 2$ min at $95^{\circ} \mathrm{C}, 45$ cycles of $15 \mathrm{~s}$ at $95^{\circ} \mathrm{C}$, and $1 \mathrm{~min}$ at $65^{\circ} \mathrm{C}$. Act was used as the internal control gene and leaf samples were used as a calibrator to normalize the values between different plates. Analysis of variance and the Duncan test were computed using the SAS ${ }^{\circledR}$ Statistical Software at $95 \%$ confidence level.

\section{EPSPS enzymatic activity}

The same eight plants used for the qRT-PCR were used here. Three leaves of each plant were combined and powdered using mortar, pestle, and liquid nitrogen. Total protein was extracted following Umesha (2006) and concentrations were determined following Bradford (1976) with bovine serum albumin as the standard. EPSPS activity was assessed by the release of inorganic phosphate when transferring the enolpyruvyl group of the PEP to the shikimate-3-phosphate (S3P). The malachite green dye assay proposed by Lanzetta et al. (1979) and modified according to Forlani et al. (1994) was used for the transfer. The reactions were measured in a $0.1-\mathrm{mL}$ final volume mixture containing $200 \mathrm{mM}$ HEPES-NaOH, $\mathrm{pH} 7.0$, $100 \mathrm{mM}$ S3P, $10 \mathrm{mM}$ PEP, $5 \mathrm{mM}$ ammonium molybdate tetrahydrate, and crude extracts. After incubation for $20 \mathrm{~min}$ at $35^{\circ} \mathrm{C}, 1 \mathrm{~mL}$ colorimetric solution and $0.1 \mathrm{~mL} 34 \%$ sodium citrate solution were added. After a 15 -min incubation period, the reactions were centrifuged for $1 \mathrm{~min}$ at $2000 \mathrm{~g}$, at room temperature. The supernatants were filtered to remove any solids. Finally, the absorbance was measured three times at $660 \mathrm{~nm}$. Analysis of variance and the Duncan test were computed using the SAS ${ }^{\circledR}$ Statistical Software at $95 \%$ confidence level.

Genetics and Molecular Research 15 (3): gmr.15038730 


\section{RESULTS}

\section{EPSPS gene sequencing}

All sequences are available at NCBI, and accession numbers are shown in Table 3 and Table S1. Genomic PCR amplification of the EPSPS gene resulted in amplicons ranging from 1161 (Matao_5) to 1196 bp (Matao_1) in resistant plants and from 887 (Mogi_8) to 1187 bp (Mogi_7) in susceptible plants. In the case of cDNA, the sizes of the resistant sequences varied from 514 (plant 3) to 706 bp (plant 1), whereas the susceptible sequences varied from 517 (plant 2) to $542 \mathrm{bp}$ (plant 4). The D. insularis DNA sequences showed similarities of 74$82 \%$, whereas the $D$. insularis cDNA sequences showed similarities of $78-94 \%$ with grasses. The highest similarities for cDNA were obtained for Oryza sativa (90\%) and Eleusine indica (94\%). The predicted proteins of all cDNA sequences were searched using the NCBI BLASTp program and showed similarities higher than $80 \%$ for all sequences.

Table 3. NCBI accession number of all sequences used in this study.

\begin{tabular}{|c|c|c|c|}
\hline Gene & Sample name & Type of molecule & NCBI accession No. \\
\hline DiAct & Act & mRNA & KX096878 \\
\hline DiEPSPS & Resist1Allele1 & mRNA & KX108889 \\
\hline DiEPSPS & Resist1Allele2 & mRNA & KX108890 \\
\hline DiEPSPS & Resist2Allele1 & mRNA & KX108891 \\
\hline DiEPSPS & Resist2Allele1 & mRNA & KX108892 \\
\hline DiEPSPS & Resist3Allele1 & mRNA & KX108893 \\
\hline DiEPSPS & Resist3Allele2 & mRNA & KX108894 \\
\hline DiEPSPS & Resist4Allele1 & mRNA & KX108895 \\
\hline DiEPSPS & Resist4Allele2 & mRNA & KX108896 \\
\hline DiEPSPS & Suscep1Allele1 & mRNA & KX108897 \\
\hline DiEPSPS & Suscep2Allele1 & mRNA & KX108898 \\
\hline DiEPSPS & Suscep3Allele1 & mRNA & KX108899 \\
\hline DiEPSPS & Suscep4Allele1 & mRNA & KX108900 \\
\hline DiEPSPS & Matao_1 & DNA & KX108901 \\
\hline DiEPSPS & Matao_2 & DNA & KX108902 \\
\hline DiEPSPS & Matao_3 & DNA & KX108903 \\
\hline DiEPSPS & Matao_4 & DNA & KX108904 \\
\hline DiEPSPS & Matao_5 & DNA & KX108905 \\
\hline DiEPSPS & Unesp_1 & DNA & KX108906 \\
\hline DiEPSPS & Unesp_2 & DNA & KX108907 \\
\hline DiEPSPS & Unesp_3 & DNA & KX108908 \\
\hline DiEPSPS & Unesp_4 & DNA & KX108909 \\
\hline DiEPSPS & Mogi_1 & DNA & KX108910 \\
\hline DiEPSPS & Mogi_2 & DNA & KX108911 \\
\hline DiEPSPS & Mogi_3 & DNA & KX108912 \\
\hline DiEPSPS & Mogi_4 & DNA & KX108913 \\
\hline DiEPSPS & Mogi_5 & DNA & KX108914 \\
\hline DiEPSPS & Mogi_6 & DNA & KX108915 \\
\hline DiEPSPS & Mogi_7 & DNA & KX108916 \\
\hline DiEPSPS & Mogi_8 & DNA & KX108917 \\
\hline
\end{tabular}

\section{Mutations in resistant plants and EPSPS gene alleles}

The sequencing and further comparison of EPSPS cDNA sequences in resistant plants showed two particular mutations (Table 4). The first one was the nucleotide substitution of 
cytosine to adenine at position 43 (first codon position), resulting in a change of the amino acid 15 (proline to threonine) (Figure 1). The second mutation was the substitution of adenine to guanine at position 428 (second codon position), resulting in a change of amino acid 143 (tyrosine to cysteine) (considering position 1 as the "EVQL" amino acids) (Figure 1). cDNA sequencing of $D$. insularis-resistant plants revealed two alleles for each plant (Figure 1). They exhibited at least one allele with the amino acids (threonine and cysteine) that confer resistance (Table 4) when translated into protein. Only plant 3 exhibited the second allele with proline instead of threonine, but having cysteine as the resistant amino acid in the first allele.

Table 4. Alleles and their respective amino acids in different Digitaria insularis-resistant plants.

\begin{tabular}{|c|c|c|c|}
\hline \multicolumn{4}{|c|}{ Resistant plant allele 1} \\
\hline Plant 1 & Plant 2 & Plant 3 & Plant 4 \\
\hline $\mathrm{P}^{*}$ & $\mathrm{P}$ & $\mathrm{P}$ & $\mathrm{P}$ \\
\hline $\mathrm{Y}^{*}$ & $\mathbf{C}$ & $\mathrm{Y}$ & $\mathrm{Y}$ \\
\hline \multicolumn{4}{|c|}{ Resistant plant allele 2} \\
\hline Plant 1 & Plant 2 & Plant 3 & Plant 4 \\
\hline$\overline{T^{\dagger}}$ & $\mathrm{T}$ & $\mathbf{P}$ & $\mathrm{T}$ \\
\hline$\overline{\mathrm{C}^{\dagger}}$ & $\mathrm{C}$ & $\mathrm{C}$ & $\mathrm{C}$ \\
\hline
\end{tabular}

*Amino acids that define susceptibility. ${ }^{\dagger}$ Amino acids that define resistance. Amino acids highlighted in bold indicate the facultative resistance described in this study.

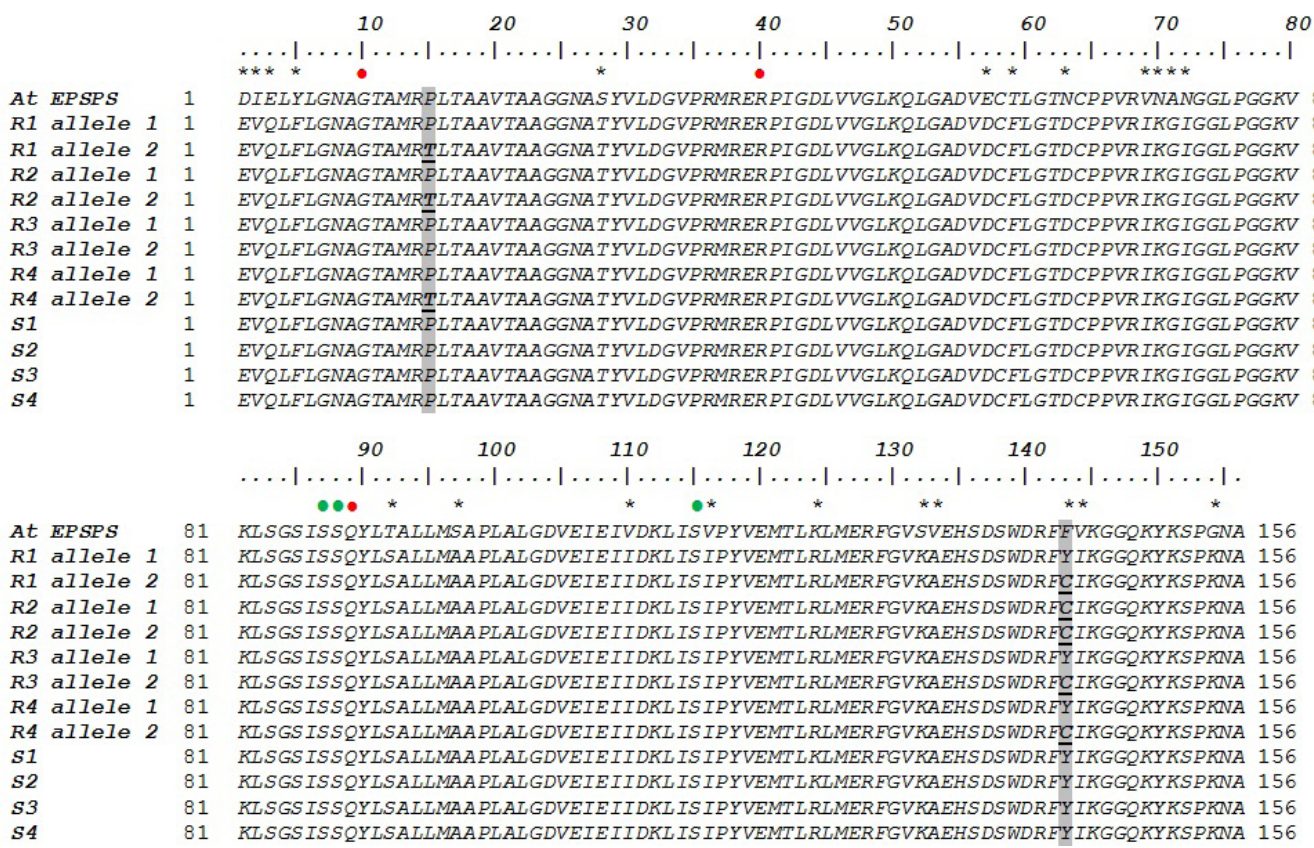

Figure 1. Partial EPSPS protein sequence alignment of resistant and susceptible Digitaria insularis plants with the Arabidopsis thaliana EPSPS sequence (GenBank accession No. CAA2982.1). Amino acids highlighted in gray indicate proline to threonine and tyrosine to cysteine substitutions in the resistant $(\mathrm{R})$ plants compared with the susceptible (S) ones. Red and green dots indicate residues ligated to glyphosate [N-(phosphonomethyl) glycine] and shikimate-3-phosphate, respectively. The asterisks indicate differences in the protein sequence between $A$. thaliana and D. insularis.

Genetics and Molecular Research 15 (3): gmr.15038730 


\section{Genetic distances using EPSPS sequences}

The distance-based cladogram revealed two groups for the resistant and susceptible plants (Figure 2). The susceptible plant group ("Mogi"), with 99\% bootstrap support, contained two subgroups, Mogi_6 and 7, and Mogi_1, 2, 3, 4, 5, and 8, including a total of eight plants with significant statistical support. Moreover, the resistant plants appeared to belong to several groups with less complexity (in terms of variability), in which all specimens showed unresolved relationships due to shorter branch lengths. The resistant group also contained fewer variable sites.

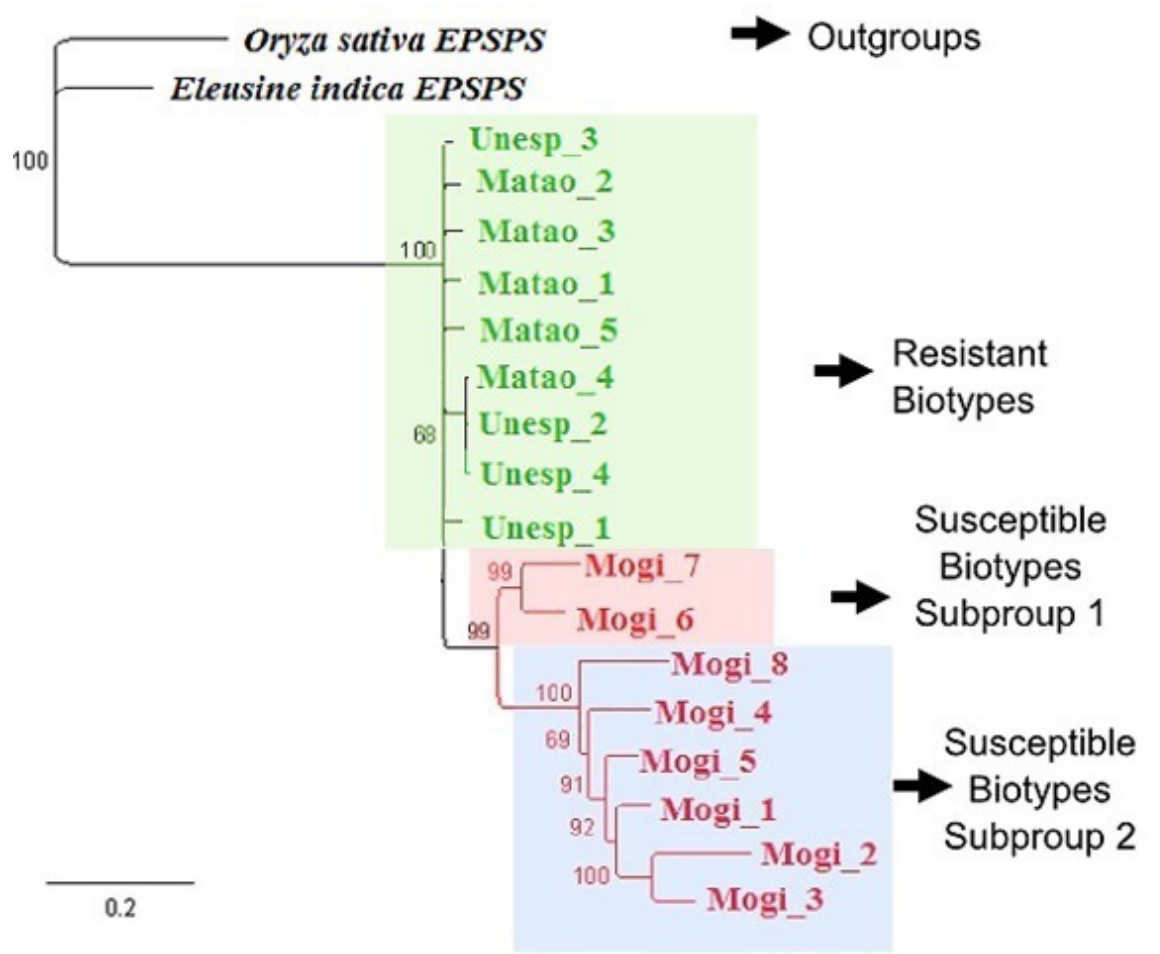

Figure 2. Maximum likelihood tree using the most conserved DNA sequences of resistant and susceptible Digitaria insularis plants. Resistant biotypes are highlighted in green letters and background. Susceptible biotypes are highlighted in red letters, subgroups 1 and 2 are further highlighted with red and blue backgrounds, respectively. Bootstrap values are provided at each node. Oryza sativa and Eleusine indica were used as outgroups. Scale bar unit is "nucleotide substitutions per site".

\section{EPSPS gene expression and enzymatic activity of $D$. insularis}

Melting curves with specific peaks for both genes (Act and EPSPS) are shown in Figure 3. The primer efficiencies and correlation coefficients were found to be suitable for subsequent analysis (Table 2). Analysis of variance and the Duncan mean test for qRT-PCR and enzymatic activity are presented in Tables 5 and 6, respectively. EPSPS gene expression without glyphosate application between the two biotypes (resistant and susceptible) was

Genetics and Molecular Research 15 (3): gmr.15038730 
statistically different. Susceptible plants presented significantly $(\mathrm{P} \leq 0.05)$ higher $(1.1$-fold higher) EPSPS expression than resistant plants (Figure 4).

In contrast, the EPSPS enzyme activity levels (Figure 5) were significantly more active (5.1-fold higher, $\mathrm{P} \leq 0.05$ ) in resistant plants than in susceptible plants. In addition, the gene expression levels gradually increased from the resistant plant 1 , followed by plants 2,3 , and 4 , consecutively (Figure 4). Inversely, enzymatic activity showed the highest value for resistant plant 1 and gradually decreased in resistant plants 2,3 , and 4 , consecutively. This indicates that there are different levels of resistance across the samples. In the susceptible plants, there was no inverse or direct relationship between gene expression and enzymatic activity.
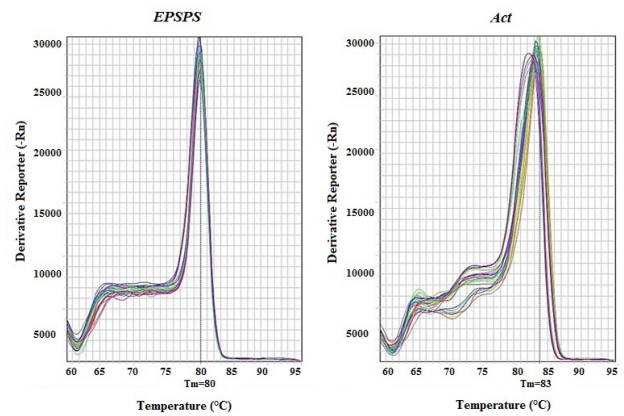

Figure 3. Melting curves for the EPSPS and Act genes of Digitaria insularis.

\begin{tabular}{|c|c|c|c|c|c|}
\hline \multicolumn{6}{|c|}{ Analysis of variance for qRT-PCR } \\
\hline Source & Sum of squares & d.f. & Mean square & F-ratio & $\mathrm{P}$ value \\
\hline Between groups & 4.95 & 1 & 4.95 & 10.56 & 0.0058 \\
\hline Within groups & 6.56 & 14 & 0.46 & & \\
\hline Total (Corr.) & 11.51 & 15 & & & \\
\hline \multicolumn{6}{|c|}{ Multiple range test-method: $95.0 \%$ Duncan } \\
\hline \multicolumn{2}{|c|}{ Type } & \multicolumn{2}{|c|}{ Count } & \multicolumn{2}{|c|}{ Mean homogeneous groups } \\
\hline \multicolumn{2}{|l|}{ Susceptible } & \multicolumn{2}{|l|}{8} & \multicolumn{2}{|l|}{$22.69 \mathrm{~A}$} \\
\hline \multicolumn{2}{|l|}{ Resistant } & \multicolumn{2}{|l|}{8} & \multicolumn{2}{|l|}{$23.81 \mathrm{~B}$} \\
\hline \multicolumn{2}{|l|}{ Contrast } & \multicolumn{2}{|c|}{ Difference } & & \\
\hline \multicolumn{2}{|c|}{ Resistant-susceptible } & \multicolumn{2}{|c|}{$0.55^{*}$} & & \\
\hline
\end{tabular}

*Denotes a statistically significant difference.

Table 6. Statistics for enzymatic activity data.

\begin{tabular}{|c|c|c|c|c|c|}
\hline \multicolumn{6}{|c|}{ Analysis of variance for enzymatic activity } \\
\hline Source & Sum of squares & d.f. & Mean square & F-ratio & $\mathrm{P}$ value \\
\hline Between groups & 1.81 & 1 & 1.81 & 6.52 & 0.0182 \\
\hline Within groups & 6.13 & 22 & 0.27 & & \\
\hline Total (Corr.) & 7.94 & 23 & & & \\
\hline \multicolumn{6}{|c|}{ Multiple range test-method: $95.0 \%$ Duncan } \\
\hline \multicolumn{2}{|l|}{ Type } & \multicolumn{2}{|c|}{ Count } & \multicolumn{2}{|c|}{ Mean homogeneous groups } \\
\hline \multicolumn{2}{|l|}{ Susceptible } & \multicolumn{2}{|l|}{12} & \multicolumn{2}{|l|}{$0.133 \mathrm{~A}$} \\
\hline \multicolumn{2}{|l|}{ Resistant } & \multicolumn{2}{|l|}{12} & \multicolumn{2}{|l|}{$0.683 \mathrm{~B}$} \\
\hline \multicolumn{2}{|l|}{ Contrast } & \multicolumn{2}{|c|}{ Difference } & & \\
\hline \multicolumn{2}{|c|}{ Resistant-susceptible } & \multicolumn{2}{|c|}{$* 0.56$} & & \\
\hline
\end{tabular}

*Denotes a statistically significant difference.

Genetics and Molecular Research 15 (3): gmr.15038730 


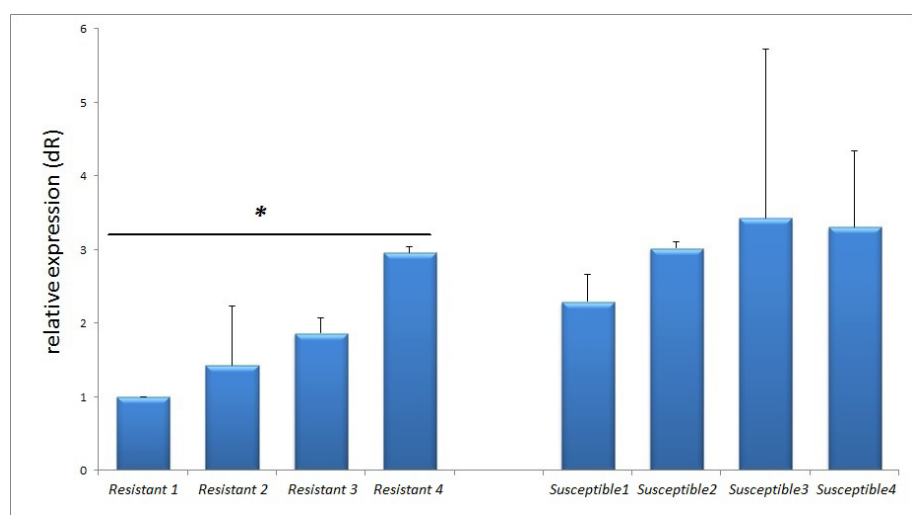

Figure 4. Expression levels of the EPSPS gene in resistant and susceptible plants of Digitaria insularis, using the Act gene for normalization. The results are reported as mean fold-changes in relative expression compared with resistant plant 1 . The error bars are the mean standard deviation calculated from three technical replicates. The asterisk indicates a significant difference between susceptible and resistant groups with $95 \%$ confidence.

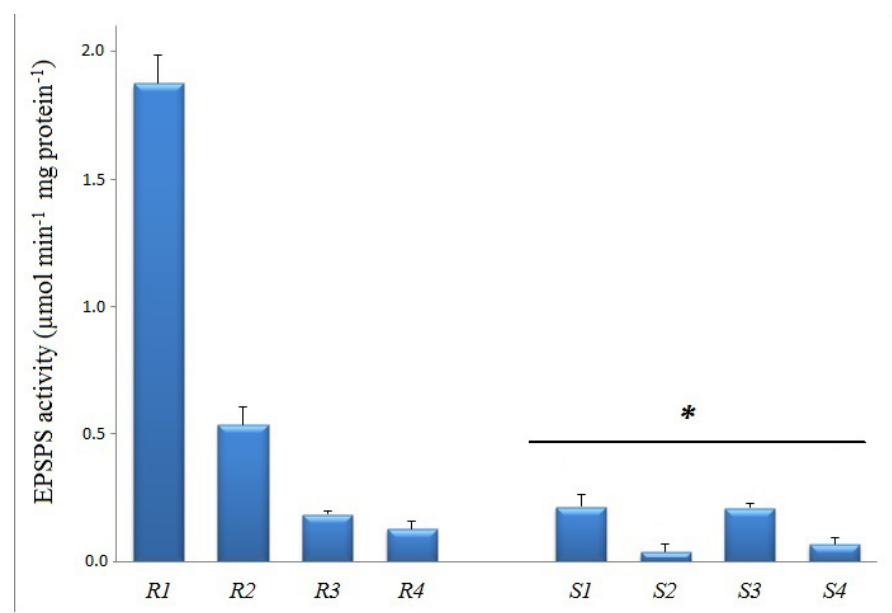

Figure 5. Digitaria insularis EPSPS activity of resistant (R) and susceptible (S) plants. Error bars represent the mean standard deviation calculated from three technical replicates. The asterisk indicates a significant difference between $\mathrm{S}$ and $\mathrm{R}$ groups with $95 \%$ confidence.

\section{DISCUSSION}

\section{EPSPS alleles and amino acid substitutions in D. insularis related to glyphosate resistance}

We first confirmed that the DNA and cDNA sequences showed identity with the EPSPS gene and subsequently investigated whether there were differences in the changes at the nucleotide and amino acids level between and within the resistant and susceptible populations. We wanted to test whether these mutations (i.e., alleles) contribute to $D$. insularis resistance to glyphosate. We found that resistant plants showed substitutions of cytosine to 
adenine (proline to threonine) and adenine to guanine (tyrosine to cysteine) (Figure 1), which corresponded to the findings by de Carvalho et al. (2012) in D. insularis and by Baerson et al. (2002b) in E. indica.

We found that all resistant plants presented at least one allele (usually cysteine) with the amino acids conferring resistance (Table 4). Several studies have shown that resistance increase is attributable to multiple copies of the EPSPS gene, such as L. perenne (Salas et al., 2012) and Amaranthus palmeri (Giacomini et al., 2014). In contrast, A. tuberculatus (Nandula et al., 2013) exhibited a single copy of the EPSPS gene, which indicates that not all grasses have the same mechanism of resistance. DNA-mediated transposon activity and unequal recombination between different genomic regions resulting in replication of the EPSPS gene have been suggested to be mechanisms for generating multiple copies (Gaines et al., 2013).

At the protein level, several alleles lead to an increase in the enzyme's affinity to bind to PEP. Previous reports have shown that the substitution of proline to serine, leucine, or threonine resulted in more glyphosate resistance in L. rigidum and L. multiflorum (Baerson et al., 2002a; Perez-Jones et al., 2007). Similarly, the presence of two EPSPS loci in susceptible A. palmeri was observed, with one being amplified in glyphosate-resistant plants (Gaines et al., 2013). A single amino acid substitution of alanine for glycine (at residue 96) in Brassica napus altered the affinity of the EPSPS gene for glyphosate (Kahrizi et al., 2007). Consequently, the second substitution observed in the present study (tyrosine to cysteine) seems to be essential to confer glyphosate resistance in $D$. insularis.

\section{EPSPS genetic distances of $D$. insularis}

The grouping of resistant and susceptible plants in two different clades was clear (Figure 2). Multiple-genetic structure studies have been performed previously in species of the Poaceae family. For example, the perennial grass Miscanthus sinensis showed low genetic differentiation among 30 populations (Shimono et al., 2013). Similarly, when using three non-coding regions of chloroplast DNA to examine population structure of 43 populations of European forest grass Hordelymus europaeus, long-distance dispersal due to a widespread ancestor was found (Dvořková et al., 2010).

In contrast, the $P A L$ gene and the intergenic spacer gene fragment rpl32-trnL were used to study the population structure and phylogeography of Camellia taliensis (Liu et al., 2012). In the 21 studied natural populations of C. taliensis (Theaceae), moderate genetic differentiation, restricted gene flow through seeds, and historical habitat fragmentation were found (Liu et al., 2012). Traditionally, DNA regions such as $r b c L$, matK, and $t r n L-F$ were used to obtain a phylogenetic tree for the Poaceae family (Bouchenak-Khelladi et al., 2008), including the Digitaria, Echinochloa, and Panicum genera. Our results for D. insularis indicate two separate groups, which are related to the susceptible and resistant groups (Figure 2). The susceptible group is located in "Mogi" and resistant biotypes are located in "Unesp" and "Matao".

Two distinct groups of $M$. sinensis were found to have a wide geographical distribution and coexisted within 43 populations studied (Shimono et al., 2013). In the present study, a high diversity in the susceptible samples, at least in subgroup 1 was evident (Figure 2). In contrast, little diversity for resistant samples could be inferred. These results suggest exposure effects to glyphosate for $D$. insularis by selection of resistant over susceptible plants and its associated genotypes.

Genetics and Molecular Research 15 (3): gmr.15038730 


\section{EPSPS gene expression and enzymatic activity of $D$. insularis}

The possible contributions of the transcriptional and translational regulation in resistance were examined. In the absence of glyphosate application, resistant $D$. insularis plants presented lower EPSPS gene expression (Figure 4) and higher EPSPS enzymatic activity (Figure 5) compared to susceptible plants, and these differences were statistically significant (Table 6). These results indicate that at least the higher enzymatic activity in resistant plants without herbicide application contributes to the resistance process in D. insularis described in this study.

Changes in the different mechanisms that usually contribute to the resistance process may be used to estimate the real contribution of each mechanism in the glyphosate resistance (Baerson et al., 2002a). In some cases, the EPSPS gene was expressed at the same level in resistant and susceptible plants, as in the case of A. tuberculatus (Nandula et al., 2013) and L. rigidum (Baerson et al., 2002a). In contrast, higher EPSPS gene expression was found in resistant plants of O. sativa (Wang et al., 2014) and Conyza spp (Dinelli et al., 2008) without glyphosate application, and in L. perenne (Salas et al., 2012) with glyphosate application. In other cases, higher gene expression and enzymatic activity appear together. For example, glyphosate-resistant plants of E. indica presented 4- and 5-fold higher EPSPS expression and EPSPS activity, respectively (Baerson et al., 2002b). Other studies have shown that even without glyphosate treatment, resistant plants have a stronger competitive ability (Vila-Aiub et al., 2009), such as the case of D. insularis in this study.

\section{Resistance biology of $D$. insularis and implications of this study}

Long periods of $D$. insularis permanence (being a perennial species) in production areas (Carvalho et al., 2013) along with periodic herbicide application most likely lead to selection of high resistant plants of this weed. The aggressive regeneration throughout the entire year due to efficient seed germination is also a notorious characteristic of this species, which is positively photoblastic and highly dependent on temperature and provenance (De Mendoça et al., 2014).

Traditionally, anatomical and physiological traits of glyphosate resistance in $D$. insularis have been identified: in resistant biotypes, significant rhizome development with a thick leaf blade and high stomata index and number per $\mathrm{mm}^{2}$ were observed (Carvalho et al., 2013; De Mendoça et al., 2014; Barroso et al., 2015). However, behind the phenotypical characters, gene structure rearrangements play essential roles in plant function, including changes in photorespiration and photosynthesis, stress response, anatomical modifications, habitat specialization, adaptation, and domestication (Barbazuk et al., 2008; Edwards and Smith, 2010).

In our survey, even with different glyphosate application, such as the citrus culture (approx. six times per year) and corn crop (approx. twice per year) (4 L per ha during 12 years in both cases) (Table 1), the consequences were the same: selection of $D$. insularisresistant plants at different levels. In Brazil, several glyphosate-resistant biotypes of this species have been observed to interfere the annual and perennial crop growth (de Carvalho et al., 2012). Chemical control is highly efficient in its initial growth stages, limiting rhizome and seed production (Carvalho et al., 2013). Removing weeds just after planting the summer annual crops is also recommended when no-till systems are used (Carvalho et al., 2013). As an observation of this study, resistance events homogenize the variability in $D$. insularis, naturally observed in susceptible biotypes, such as in "Mogi" plants (Figure 2). The resistant

Genetics and Molecular Research 15 (3): gmr.15038730 
biotypes surveyed in "Unesp" and "Matao" showed similar variability, being clustered in the same group (Figure 2).

In this study, new molecular explanations to the biological response for glyphosate resistance in $D$. insularis have been identified. These mechanisms appear to be integrated: 1) The substitution of proline to threonine and tyrosine to cysteine (Table $4, \mathrm{~T}+\mathrm{C}$ vs $\mathrm{P}+\mathrm{C}$ ) was observed as described previously by de Carvalho et al. (2012). However, at least two alleles were found in our study that exhibited facultative resistance. Not all the resistant plants presented threonine, but the cysteine amino acid seems to be essential to confer glyphosate resistance in D. insularis (Table 4). 2) Even with the geographical separation of some resistant biotypes existing in São Paulo State, the biotypes do not show genetic variability when DNA sequences without introns are used for the analysis. 3) In resistant plants, EPSPS gene expression and enzymatic activity were lower and higher than in susceptible plants, respectively, at different levels, but without a link with the types of alleles or the amino acid substitutions. These new molecular aspects illustrate that the resistance process is much more complex than we expected, with several target- and non-target-site mechanisms complicating the management and herbicide application.

To conclude, our results suggest that: 1) Mutations in one or both alleles of the EPSPS gene confer resistance, possibly with one or two amino acid substitutions (facultative resistance). 2) We identified low diversity at the local scale in the genetic pool of resistant $D$. insularis biotypes due to herbicide control. 3) $D$. insularis resistance is most likely associated with regulation related to increased levels of EPSPS enzymatic activity that is not directly related to gene expression. 4) D. insularis has several target- and non-target-site mechanisms for glyphosate resistance.

To increase our knowledge on the biology and molecular aspects of the resistance in D. insularis, it is critical to develop efficient strategies for its control. Similarly, more evidence about the cause and effect relationship between variability and herbicide application is essential. We used a relatively small sample size and sampled only a few locations. There is therefore the potential that bottleneck events other than glyphosate application are involved. This study has elucidated new genetic aspects of glyphosate resistance process in $D$. insularis.

\section{Conflicts of interest}

The authors declare no conflict of interest.

\section{ACKNOWLEDGMENTS}

The authors thank Flavio dos Santos for his help in the DNA extraction process and Valentina de Fátima De Martin for sequencing all the samples. E. Galeano, A.A.M. Barroso, T.S. Vasconcelos, and A.J.P. Albretch were supported by "Fundação de Amparo à Pesquisa do Estado de São Paulo" (FAPESP - fellowship processes \#2013/06299-8, \#2012/10372-0, \#2010/19294-6, and \#2012/10371-3, respectively).

\section{REFERENCES}

Baerson SR, Tran M and Brinker R (2000). Characterization of a glyphosate-resistant Eleusine indica biotype from Malaysia. In: International Weed Control Congress. International Weed Science Society, Bangkok, 150.

Genetics and Molecular Research 15 (3): gmr.15038730 
Baerson SR, Rodriguez DJ, Biest N, Tran M, et al. (2002a). Investigating the mechanism of glyphosate resistance in rigid ryegrass (Lolium ridigum). Weed Sci. 50: 721-730. http://dx.doi.org/10.1614/0043-1745(2002)050[0721:ITMOGR ]2.0.CO;2

Baerson SR, Rodriguez DJ, Tran M, Feng Y, et al. (2002b). Glyphosate-resistant goosegrass. Identification of a mutation in the target enzyme 5-enolpyruvylshikimate-3-phosphate synthase. Plant Physiol. 129: 1265-1275.http://dx.doi. org/10.1104/pp.001560

Barbazuk WB, Fu Y and McGinnis KM (2008). Genome-wide analyses of alternative splicing in plants: opportunities and challenges. Genome Res. 18: 1381-1392. http://dx.doi.org/10.1101/gr.053678.106

Barroso AAM, Galeano E, Albrecht AJP, dos Reis FC, et al. (2015). Does sourgrass leaf anatomy influence glyphosate resistance? Comun. Sci. 6: 445-453. http://dx.doi.org/10.14295/cs.v6i4.1124

Bouchenak-Khelladi Y, Salamin N, Savolainen V, Forest F, et al. (2008). Large multi-gene phylogenetic trees of the grasses (Poaceae): progress towards complete tribal and generic level sampling. Mol. Phylogenet. Evol. 47: 488-505. http://dx.doi.org/10.1016/j.ympev.2008.01.035

Bradford MM (1976). A rapid and sensitive method for the quantitation of microgram quantities of protein utilizing the principle of protein-dye binding. Anal. Biochem. 72: 248-254. http://dx.doi.org/10.1016/0003-2697(76)90527-3

Carvalho LB, Bianco MS and Bianco S (2013). Accumulation of dry mass and macronutrients by sourgrass plants. Planta Daninha 31: 785-792. http://dx.doi.org/10.1590/S0100-83582013000400004

Chandi A, Milla-Lewis SR, Giacomini D, Westra P, et al. (2012). Inheritance of evolved glyphosate resistance in a North Carolina palmer amaranth (Amaranthus palmeri) biotype. Int. J. Agron. 2012: 1-7.

de Carvalho LB, Cruz-Hipolito H, González-Torralva F, Alves PLCA, et al. (2011). Detection of sourgrass (Digitaria insularis) biotypes resistant to glyphosate in Brazil. Weed Sci. 59: 171-176. http://dx.doi.org/10.1614/WS-D-10$\underline{00113.1}$

de Carvalho LB, Alves PL, González-Torralva F, Cruz-Hipolito HE, et al. (2012). Pool of resistance mechanisms to glyphosate in Digitaria insularis. J. Agric. Food Chem. 60: 615-622.http://dx.doi.org/10.1021/jf204089d

De Mendoça GS, Martins CC, Martins D and da Costa NV (2014). Ecophysiology of seed germination in Digitaria insularis ((L.) Fedde). Rev. Cienc. Agr. Agron. 45: 823-832. http://dx.doi.org/10.1590/S1806-66902014000400021

Dinelli G, Marotti I, Catizone P, Bonetti A, et al. (2008). Physiological and molecular basis of glyphosate resistance in C. bonariensis (L.) Cronq. biotypes from Spain. Weed Res. 48: 257-265. http://dx.doi.org/10.1111/j.13653180.2008.00623.x

Doyle JJ and Doyle JL (1987). A rapid DNA isolation procedure for small quantities of fresh leaf tissue. Phytochem. Bull. 19: 11-15.

Dvořková H, Fér T and Marhold K (2010). Phylogeographic pattern of the European forest grass species Hordelymus europaeus: cpDNA evidence. Flora Morphol. Distrib. Funct. Ecol. Plants 205: 418-423. http://dx.doi.org/10.1016/j. flora.2009.12.029

Edwards EJ and Smith SA (2010). Phylogenetic analyses reveal the shady history of C4 grasses. Proc. Natl. Acad. Sci. USA 107: 2532-2537.http://dx.doi.org/10.1073/pnas.0909672107

Finn RD, Bateman A, Clements J, Coggill P, et al. (2014). Pfam: the protein families database. Nucleic Acids Res. 42: D222-D230.http://dx.doi.org/10.1093/nar/gkt1223

Forlani G, Parisi B and Nielsen E (1994). 5-enol-pyruvyl-shikimate-3-phosphate synthase from Zea mays cultured cells (purification and properties). Plant Physiol. 105: 1107-1114.

Franz JE, Mao MK and Sikorski JA (1997). Glyphosate: a unique global herbicide. The University of Virginia, Charlottesville.

Gaines TA, Wright AA, Molin WT, Lorentz L, et al. (2013). Identification of genetic elements associated with EPSPs gene amplification. PLoS One 8: e65819.http://dx.doi.org/10.1371/journal.pone.0065819

Gasteiger E, Gattiker A, Hoogland C, Ivanyi I, et al. (2003). ExPASy: The proteomics server for in-depth protein knowledge and analysis. Nucleic Acids Res. 31: 3784-3788. http://dx.doi.org/10.1093/nar/gkg563

Ge X, d'Avignon DA, Ackerman JJ and Sammons RD (2010). Rapid vacuolar sequestration: the horseweed glyphosate resistance mechanism. Pest Manag. Sci. 66: 345-348.

Gemelli A, Oliveira RS, Junior., Constantin J, Pereira Braz GB, et al. (2012). Aspectos da biologia de Digitaria insularis resistente ao glyphosate e implicações para o seu controle. Rev. Bras. Herbic. 11: 231-240.

Giacomini D, Westra P and Ward SM (2014). Impact of genetic background in fitness cost studies: An example from glyphosate-resistant palmer amaranth. Weed Sci. 62: 29-37. http://dx.doi.org/10.1614/WS-D-13-00066.1

Hall T (1999). BioEdit: a user-friendly biological sequence alignment editor and analysis program for Windows 95/98/ NT. Nucleic Acids Symp. Ser. 41: 95-98.

Kahrizi D, Salmanian AH, Afshari A, Moieni A, et al. (2007). Simultaneous substitution of Gly96 to Ala and Ala183 to Thr in 5-enolpyruvylshikimate-3-phosphate synthase gene of E. coli (k12) and transformation of rapeseed (Brassica napus L.) in order to make tolerance to glyphosate. Plant Cell Rep. 26: 95-104. http://dx.doi.org/10.1007/s00299$\underline{006-0208-4}$

Genetics and Molecular Research 15 (3): gmr.15038730 
Kimura M (1980). A simple method for estimating evolutionary rates of base substitutions through comparative studies of nucleotide sequences. J. Mol. Evol. 16: 111-120. http://dx.doi.org/10.1007/BF01731581

Lanzetta PA, Alvarez LJ, Reinach PS and Candia OA (1979). An improved assay for nanomole amounts of inorganic phosphate. Anal. Biochem. 100: 95-97.http://dx.doi.org/10.1016/0003-2697(79)90115-5

Larkin MA, Blackshields G, Brown NP, Chenna R, et al. (2007). Clustal W and Clustal X version 2.0. Bioinformatics 23: 2947-2948. http://dx.doi.org/10.1093/bioinformatics/btm404

Liu F and Cao YP (2015). Cloning and characterization of 5-enopyruvylshikimate-3-phosphate synthase from Pantoea sp. Genet. Mol. Res. 14: 19233-19241.http://dx.doi.org/10.4238/2015.December.29.33

Liu Y, Yang SX, Ji PZ and Gao LZ (2012). Phylogeography of Camellia taliensis (Theaceae) inferred from chloroplast and nuclear DNA: insights into evolutionary history and conservation. BMC Evol. Biol. 12: 92. http://dx.doi. org/10.1186/1471-2148-12-92

Machado AFL, Ferreira LR, Ferreira FA, Fialho CMT, et al. (2006). Análise de crescimento de Digitaria insularis. Planta Daninha 24: 641-647. http://dx.doi.org/10.1590/S0100-83582006000400004

Machado AFL, Meira RMS, Ferreira LR, Ferreira FA, et al. (2008). Caracterização anatômica de folha, colmo e rizoma de Digitaria insularis. Planta Daninha 26: 1-8. http://dx.doi.org/10.1590/S0100-83582008000100001

Manalil S, Busi R, Renton M and Powles SB (2011). Rapid evolution of herbicide resistance by low herbicide dosages. Weed Sci. 59: 210-217. http://dx.doi.org/10.1614/WS-D-10-00111.1

Mondo VHV, Carvalho SJP, Dias ACR and Marcos Filho J (2010). Efeitos da luz e temperatura na germinação de sementes de quatro espécies de plantas daninhas do gênero Digitaria. Rev. Bras. Sementes 32: 131-137. http://dx.doi. org/10.1590/S0101-31222010000100015

Nandula VK, Ray JD, Ribeiro DN, Pan Z, et al. (2013). Glyphosate resistance in tall waterhemp (Amaranthus tuberculatus) from Mississippi is due to both altered target-site and nontarget-site mechanisms. Weed Sci. 61: 374-383. http:// dx.doi.org/10.1614/WS-D-12-00155.1

Perez-Jones A, Park KW, Polge N, Colquhoun J, et al. (2007). Investigating the mechanisms of glyphosate resistance in Lolium multiflorum. Planta 226: 395-404. http://dx.doi.org/10.1007/s00425-007-0490-6

Preston C and Wakelin AM (2008). Resistance to glyphosate from altered herbicide translocation patterns. Pest Manag. Sci. 64: 372-376. http://dx.doi.org/10.1002/ps.1489

Salas RA, Dayan FE, Pan Z, Watson SB, et al. (2012). EPSPS gene amplification in glyphosate-resistant Italian ryegrass (Lolium perenne ssp. multiflorum) from Arkansas. Pest Manag. Sci. 68: 1223-1230. http://dx.doi.org/10.1002/ ps. 3342

Shaner DL, Lindenmeyer RB and Ostlie MH (2012). What have the mechanisms of resistance to glyphosate taught us? Pest Manag. Sci. 68: 3-9.http://dx.doi.org/10.1002/ps.2261

Shimono Y, Kurokawa S, Nishida T, Ikeda H, et al. (2013). Phylogeography based on intraspecific sequence variation in chloroplast DNA of Miscanthus sinensis (Poaceae), a native pioneer grass in Japan. Botany 91: 449-456. http:// dx.doi.org/10.1139/cjb-2012-0212

Umesha S (2006). Phenylalanine ammonia lyase activity in tomato seedlings and its relationship to bacterial canker disease resistance. Phytoparasitica 34: 68-71. http://dx.doi.org/10.1007/BF02981341

Vila-Aiub MM, Neve P and Powles SB (2009). Fitness costs associated with evolved herbicide resistance alleles in plants. New Phytol. 184: 751-767.http://dx.doi.org/10.1111/j.1469-8137.2009.03055.x

Wang W, Xia H, Yang X, Xu T, et al. (2014). A novel 5-enolpyruvoylshikimate-3-phosphate (EPSP) synthase transgene for glyphosate resistance stimulates growth and fecundity in weedy rice (Oryza sativa) without herbicide. New Phytol. 202: 679-688. http://dx.doi.org/10.1111/nph.12428

Woodburn AT (2000). Glyphosate: production, pricing and use worldwide. Pest Manag. Sci. 56: 309-312. http://dx.doi. org/10.1002/(SICI)1526-4998(200004)56:4<309::AID-PS143>3.0.CO;2-C

Yu Q, Cairns A and Powles S (2007). Glyphosate, paraquat and ACCase multiple herbicide resistance evolved in a Lolium rigidum biotype. Planta 225: 499-513.http://dx.doi.org/10.1007/s00425-006-0364-3

\section{Supplementary material}

Table S1. Digitaria insularis sequences obtained from the resistant and susceptible plants. The genomic DNA sequences were used for the genetic variability analysis. The mRNA sequences were used to identify alleles and to perform the qRT-PCR.

Genetics and Molecular Research 15 (3): gmr.15038730 